\title{
The Effect of Accountability, Transparency, and Supervision on Budget Performance by Using The Concept of Value for Money in Regional Business Enterprises (BUMD) of Riau Province
}

Suharyono $^{1}$

\section{ARTICLE INFO}

Submitted : 01.07.2019

Revised : 17.09.2019

Accepted : 12.10.2019

Available : 30.12.2019

iThenticate similarity

score: $18 \%$

JEL classification:

$\mathrm{H} 11, \mathrm{H} 60, \mathrm{H} 83$

Keywords:

Accountability,

Transparency,

Supervision, Budget

Performance

\begin{abstract}
A B S T R A C T
The aim of this study is to know the effect of accountability, transparency, and supervision on budget performance in regional owned enterprises (BUMD) both simultaneously and partially. The design of this study is included in associative causal research. The population of this study is all Government employees in Riau province. The sample selection is by using the purposive sampling method, which is included by the employees of The Accounting and The Internal Supervisory Department (SPI). The collecting data technique is by using the questionnaire system. The data analysis technique used is simple regression analysis and multiple regression analysis. The results showed that the accountability, transparency, and supervision both partially and simultaneously has a positive and significant effect on budget performance with the concept of value for money in Regional Owned Enterprises (BUMD) of Riau province.
\end{abstract}

\section{Introduction}

\subsection{Background}

Since the implementation of regional autonomy, there have been the logical consequences which forming into demands to organize a government based on good governance system. Regional finance is not only related to the Regional Revenue and

Cite this article as: Suharyono. (2019). "The Effect of Accountability, Transparency, And Supervision on Budget Performance by Using The Concept of Value For Money in Regional Business Enterprises (BUMD) of Riau Province", International Journal of Public Finance, 4(2), 236-249.

\footnotetext{
1 ORCID: 0000-0001-5820-9219, Program Studi D4 Akuntansi Keuangan Publik, Indonesia, suharyono@polbeng.ac.id
} 
Expenditure Budget (APBD), but also the budgets of companies incorporated in Regional-Owned Enterprises (BUMD) as stipulated in Law No. 17 of 2003 concerning State Finance and Government Regulation No. 58 of 2005 concerning about Regional Financial Management stating that assets separated from regional companies are part of the wealth of the state / region. In general, the establishment of BUMD aims to contribute to regional economic development and become a source of Regional Original Income (PAD). But the facts show that most BUMDs in Indonesia still have the bad performance.

The case shows about the fact is that BUMD in Riau Province still has a minimal contribution to Regional Original Income. Even though the enhancement of funds through the APBD sustainably given. In addition to the poor performance, BUMD is also used as a means to commit fraud and inefficiencies. The existence of such cases shows that the management of BUMD has not been managed properly due to the ineffectiveness of planning and control functions and the principle of transparency and accountability. BUMD is a regional-owned business entity which the main purpose is to serve the public. This indicates that the BUMD should implement the principle of accountability, transparency and accountability in managing the budget, while the manifestation of these three principles is the making of an accountability report. In managing the budget must be accountability and transparency, considering that one of the important elements of the realization of Good Corporate Governance (GCG) is the management of good budget. In order for budget management to run well and on target, supervision from direct superiors and legislative bodies and supervisory institutions is specifically set up to control budget planning and implementation. The existence of supervision will make the budget planning that is arranged would run efficiently, effectively and economically.

Supervision of PDAMs in the inspection process of all government activities with the aim these activities can be carried out in line with the applicable law. There is supervising that allows deviant practices. One aspect of supervision is inspection. The supervision aims to assess whether it is the way it should be. Means the aim of monitoring the discussion of what really happened and comparing it with what happened, so that improving the theory can indicate that changes in irregularities can be detected and corrected immediately. Besides that there is a detection of irregularities that can be used as a warning for the organization, that they must increase their awareness.

\section{Review of Literature}

\subsection{Previous Research}

The pevious reaserch did by Lidiia Hladchenko (2016) about government financial accountability and transparency in the digital world. He research explains the significance of financial accountability for the economic improvement and civil society 
development. The study defines the instruments that contribute to government accountability in the digital world. The key problems of ensuring financial accountability and transparency in Ukraine are analyzed. The study focuses on information and communication technology capacity in supporting government performance. The conclusions summarize the main findings of the research.

Setiawan (2016) analyze the influence of public accountability, public transparency and control to the Regional Working Unit (SKPD) performance with the local financial management as a variable intervening. The population in this study is SKPD environment Bungo district government. The simultaneous and partial test of the hypothesis is done with test " $\mathrm{F}$ " and test " $\mathrm{t}$ " using the path analysis method. Results shows that simultaneously public accountability, public transparency, control, and local financial management, affect the performance of SKPD in Bungo district government. Partially, public accountability, public transparency, control, and local financial management affect the performance of SKPD in Bungo district government. Results shows that simultaneously public accountability, public transparency, and control, affect to local financial management. Partially public accountability, pubic transparency and control affect on local financial management, so that local financial management is not an intervening variable in this study.

Osho and Afolabi (2014) analyze the effects and effectiveness of Accountability and Transparency in Government Sectors. The study examined and ascertained the extent to which accountability, effectiveness and efficiency mechanism are being promoted and the problems that serve as hindrances to this in Ekiti State. All the data used were both the primary and secondary. Data were primarily gathered through questionnaires administered to the employees of the Nigerian Government Enterprises selected from ministries of Health, Education, Agriculture and Finance sectors at all levels of management. Secondary data were obtained through various magazines of professional associations in Nigeria, journals, newspaper and text books etc and mostly through the internet. Cross tabulation and chi-square were used to analysed the data and the study revealed that the internal control system in the state are very weak, accountability are as well ineffective due to political interference. Base on the findings, effective internal control systems that are free from interference will be needed. This will require political will at both the federal, state and local government areas.

Surianti and Dalimunthe (2017) did the research about the implementation of performance based budgeting in public sector (Indonesia case: a literature review). The author conducted literature review to analyze and evaluate the implementation of performance-based budgeting in Indonesia. The Indonesian government has to reform government financial management since 2003 by Act No. 17 of 2003. The law governing the Integrated Budget Implementation, Performance-Based Budgeting, and the Medium Term Expenditure Framework (MTEF). Indonesia is a developing country, which has different characteristics from developed countries, so that the obstacles encountered in the implementation of performance-based budgeting differently. 
Based on the results of the literature review, concluded that the grand design of performance-based budgeting set by the Indonesian government in accordance with existing literature. However, various studies in Indonesia showed that the implementation of performance-based budgeting, both at the central and local governments are still not in accordance with a predetermined grand design.

Saputra (2014) also did the research about effect of transparency, accountability and commitment of both organizations jointly or separately on the performance SKPDs South Aceh. The population in this study is the institution/agency, namely SKPK which includes offices, government offices and agencies in South Aceh district as much as 25 SKPK. Each SKPK consists of three (3) persons who will be the respondent, so the total respondents were 75 people. Research data collection techniques by distributing questionnaires to the respondents of the study. Data analysis technique used in this research is multiple linear regression analysis. This study shows the results of that transparency, accountability and commitment of both organizations jointly or separately affect the performance SKPDs South Aceh.

Surianti and Dalimunthe (2017) did the research about the implementation of performance based budgeting in public sector (Indonesia case: a literature review). The author conducted literature review to analyze and evaluate the implementation of performance-based budgeting in Indonesia. The Indonesian government has to reform government financial management since 2003 by Act No. 17 of 2003. The law governing the Integrated Budget Implementation, Performance-Based Budgeting, and the Medium Term Expenditure Framework (MTEF). Indonesia is a developing country, which has different characteristics from developed countries, so that the obstacles encountered in the implementation of performance-based budgeting differently. Based on the results of the literature review, concluded that the grand design of performance-based budgeting set by the Indonesian government in accordance with existing literature. However, various studies in Indonesia showed that the implementation of performance-based budgeting, both at the central and local governments are still not in accordance with a predetermined grand design.

\subsection{Accountability}

Accountability is the responsibility of the trustee to manage, report and disclose all activities related to the mandate to the trustee. Accountability can be measured through five indicators, namely (1) A decision-making process that is made in writing is available to stakeholders who need it, every decision taken has met ethical standards and values that apply, and in accordance with the correct administrative principles, (2) Accuracy and completeness of information relating to ways to achieve the objectives of a program, (3) Clarity of policy objectives that have been taken and communicated, (4) Dissemination of information about a decision through the media during the public access to information on a decision after a decision is made and 
public complaints mechanisms, (5) management information systems for monitoring results (Loina Lalolo Krina P: 2003).

\subsection{Transparency}

Transparency is an openness of the government to the public about all information related to the administration of government activities. Transparency can be measured through four indicators, namely (1) the existence of a legal framework for transparency, (2) the existence of public access to budget transparency, (3) the existence of an independent and effective audit, and (4) the existence of community involvement.

\subsection{Supervision}

Supervision is a process of thorough inspection of all government activities with the aim that these activities can run according to the applicable legislation. Supervision can be measured through three indicators, namely (1) Input (input) supervision, (2) Monitoring process, (3) Output (output) supervision (Gaspersz, 1998: 287) in Rezky Mulya Anugriani (2014).

So that budget performance is a budget system that prioritizes achievement of results (output) which is based on three principles, namely economical, efficient, and effectiveness. Value for Money can be measured through two indicators, namely (1) Cost allocation (economy and efficiency), (2) Service quality (effectiveness) (Mardiasmo, 2002: 130).

\section{Research Methods}

This research is a causal associative study. Associative causal research is a study that intends to describe and test the hypothesis of the relationship of two or more variables (Sugiyono, 2013). This study tested the hypothesis, namely the influence of independent variables on the dependent variable.

Independent variables are variables that influence or become the cause of changes or the emergence of dependent or bound variables. The independent variables in this study are:

1. Accountability, which is the responsibility of the trustee to manage, report and disclose all activities related to the mandate to the trustee,

2. Transparency, namely the principle that guarantees access or freedom for everyone to obtain information about the administration of government, namely information about policies, the process of making and implementing them, and the results achieved, and 
3. Supervision, which is a process of a thorough examination of all government activities with the aim that the activity can run according to the applicable legislation.

While the dependent variable is a variable that is influenced or is a result, because of the existence of independent variables. The dependent variable in this study is budget performance with the concept of value for money. Performance is an activity that aims to achieve the expected results.

Picture 1. Research Model

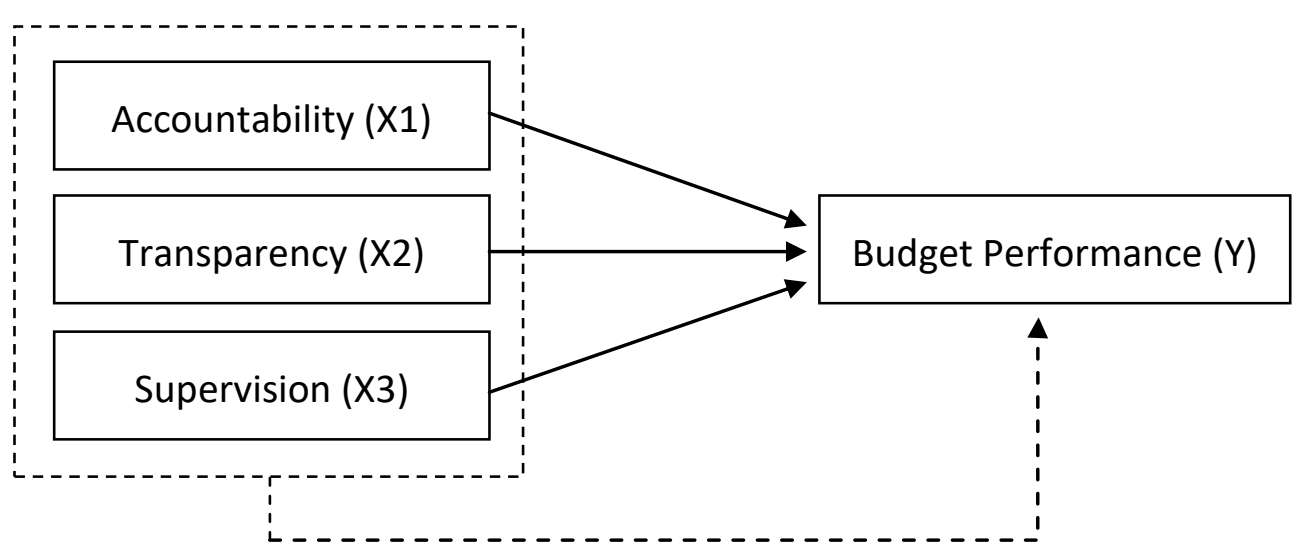

Source: Author' elaboration.

While the dependent variable is a variable that is influenced or is a result, because of the existence of independent variables. The dependent variable in this study is budget performance with the concept of value for money. Performance is an activity that aims to achieve the expected results.

\section{Research Result}

\subsection{Descriptive Analysis}

The result of the descriptive analysis is the simplification of respondent data in the form of research respondents. The results of the descriptive analysis can be seen in the following table.

Table 1 shows the characteristics of respondents from 55 questionnaires used in data processing. The table shows that male employees dominate more than female employees. Most employees are 20 to 30 years old. The majority of the employees' last education is Bachelor (S1) with a percentage of $84 \%$. 
Suharyono. (2019). "The Effect of Accountability, Transparency, and Supervision on Budget

Performance", International Journal of Public Finance, 4(2), 236-249.

Table 1: The characteristics of respondents

\begin{tabular}{|c|c|c|c|c|}
\hline No & Characteristics & Description & Frequency & Percentage \\
\hline 1 & \multirow{2}{*}{ Gender } & Male & 40 & $73 \%$ \\
\hline \multirow{2}{*}{2} & \multirow{3}{*}{ Education } & Female & 15 & $27 \%$ \\
\cline { 3 - 5 } & & Senior High School & 0 & $0 \%$ \\
\cline { 3 - 5 } & & Diploma & 7 & $13 \%$ \\
\cline { 3 - 5 } & & Bachelor (S1) & 46 & $84 \%$ \\
\hline \multirow{2}{*}{3} & \multirow{3}{*}{ Age } & Master (S2) & 2 & $4 \%$ \\
\cline { 3 - 5 } & & $20-30$ & 25 & $45 \%$ \\
\cline { 3 - 5 } & & $31-40$ & 8 & $15 \%$ \\
\cline { 3 - 5 } & & $41-50$ & 12 & $22 \%$ \\
\cline { 3 - 5 } & & $>50$ & 10 & $18 \%$ \\
\hline & Amount & & $\mathbf{5 5}$ & $100 \%$ \\
\hline
\end{tabular}

Source: Author' elaboration.

Table 2. Descriptive Statistics

\begin{tabular}{|l|c|c|c|c|}
\hline \multicolumn{1}{|c|}{ Scale } & Accountability & Transparency & Supervision & $\begin{array}{c}\text { Budget } \\
\text { Performance }\end{array}$ \\
\hline 1 = Strongly Disagree & $2.68 \%$ & $1.92 \%$ & $1.92 \%$ & $2.51 \%$ \\
2 = Disagree & $6.13 \%$ & $4.41 \%$ & $2.30 \%$ & $1.72 \%$ \\
3 = Neutral & $12.07 \%$ & $11.88 \%$ & $9.96 \%$ & $9.56 \%$ \\
4 = Agree & $50.38 \%$ & $55.75 \%$ & $62.45 \%$ & $67.24 \%$ \\
5 = Strongly Agree & $17.62 \%$ & $26.04 \%$ & $23.37 \%$ & $18.97 \%$ \\
\hline 5 =Strongly Disagree * & $1.53 \%$ & & & \\
4 = Disagree * & $4.41 \%$ & & & \\
3 = Neutral * & $1.53 \%$ & & & \\
2 = Agree * & $3.46 \%$ & & & \\
1 = Strongly Agree * & $0.19 \%$ & $100 \%$ & $100 \%$ & $100 \%$ \\
\hline \multicolumn{1}{|c|}{ Total } & $100 \%$ & 35.5 & 36.22 & 35.6 \\
\hline \multicolumn{1}{|c|}{ Average } & 34.31 & 4.570 & 4.445 & 4.572 \\
\hline \multicolumn{2}{|c|}{ Standard Deviation } & 4.374 & &
\end{tabular}

Source: Author' elaboration.

\subsection{Validity, Reliability and Normality test}

The following is a table of results from testing item validity instruments using a data processing program: 
Suharyono. (2019). "The Effect of Accountability, Transparency, and Supervision on Budget Performance", International Journal of Public Finance, 4(2), 236-249.

Table 3. Validity Test

\begin{tabular}{|c|c|c|c|}
\hline No & Questionnaire Item & Cross Loading & Description \\
\hline \multirow[t]{9}{*}{1} & ACC1 & 0.733 & Valid \\
\hline & ACC2 & 0.796 & Valid \\
\hline & ACC3 & 0.773 & Valid \\
\hline & ACC4 & -0.123 & Invalid \\
\hline & ACC5 & 0.047 & Invalid \\
\hline & ACC6 & 0.871 & Valid \\
\hline & ACC7 & 0.717 & Valid \\
\hline & ACC8 & 0.110 & Invalid \\
\hline & ACC9 & 0.219 & Invalid \\
\hline \multirow[t]{9}{*}{2} & TR1 & 0.153 & Invalid \\
\hline & TR2 & 0.795 & Valid \\
\hline & TR3 & 0.831 & Valid \\
\hline & TR4 & 0.789 & Valid \\
\hline & TR5 & 0.799 & Valid \\
\hline & TR6 & 0.720 & Valid \\
\hline & TR7 & 0.818 & Valid \\
\hline & TR8 & 0.448 & Invalid \\
\hline & TR9 & -0.059 & Invalid \\
\hline \multirow[t]{9}{*}{3} & SUP1 & 0.770 & Valid \\
\hline & SUP2 & 0.680 & Valid \\
\hline & SUP3 & -0.226 & Invalid \\
\hline & SUP4 & 0.431 & Invalid \\
\hline & SUP5 & 0.737 & Valid \\
\hline & SUP6 & 0.726 & Valid \\
\hline & SUP7 & 0.641 & Valid \\
\hline & SUP8 & 0.671 & Valid \\
\hline & SUP9 & 0.489 & Invalid \\
\hline \multirow[t]{11}{*}{4} & BP1 & 0.460 & Invalid \\
\hline & BP2 & 0.850 & Valid \\
\hline & BP3 & 0.234 & Invalid \\
\hline & BP4 & 0.787 & Valid \\
\hline & BP5 & 0.249 & Invalid \\
\hline & BP6 & 0.235 & Invalid \\
\hline & BP7 & 0.742 & Valid \\
\hline & BP8 & -0.067 & Invalid \\
\hline & BP9 & 0.828 & Valid \\
\hline & BP10 & 0.904 & Valid \\
\hline & BP11 & 0.861 & Valid \\
\hline
\end{tabular}

Source: Author' elaboration.

The Cross Loading results shown in Table 3 show that the Cross Loading value is greater than 0.50 (>0.50), which means the level of validity is partially significant. Except Accountability variable there are instruments 4, 5, 8 and 9, Transparency variables on instruments 1.8 and 9, Supervision variable on instruments 3,4 and 9, and variables Budget performance on instruments 1, 3, 5, 6 and 8 which have a Cross Loading value of less than $0.50(<0.50)$, so that the instrument cannot be used in further testing.

The following is a table of reliability test results using a data processing program: 
Table 4. Reliability Test

\begin{tabular}{|c|c|c|c|c|}
\hline No & Variable & $\begin{array}{c}\text { Cronbach's } \\
\text { Alpha }\end{array}$ & $\begin{array}{c}\text { Cronbach's Alpha Based on } \\
\text { Standardized Items }\end{array}$ & N of Items \\
\hline 1 & Accountability (X1) & 0.712 & 0.761 & 9 \\
\hline 2 & Transparency $(\mathrm{X} 2)$ & 0.800 & 0.824 & 9 \\
\hline 3 & Supervision(X3) & 0.843 & 0.847 & 9 \\
\hline 4 & Budget Performance $(\mathrm{Y})$ & 0.863 & 0.876 & 11 \\
\hline
\end{tabular}

Source: Author' elaboration.

From the table above it can be seen that the reliability test results, the value of Cronbanch's Alpha produced 0.876>0.70 indicates that the construct of this research variable is reliable.

In this study, the data normality test is carried out using Kolmogorov-Smirnov. Data normality test results are as follows:

Table 5. Results of Normality test

\begin{tabular}{|c|c|c|c|c|}
\hline No & Item & Sig & $\%$ & Information \\
\hline 1 & Accountability (X1) & 0.069 & 0.05 & Normal \\
\hline 2 & Transparency (X2) & 0.053 & 0.05 & Normal \\
\hline 3 & Supervision(X3) & 0.054 & 0.05 & Normal \\
\hline 4 & Budget Performance $(\mathrm{Y})$ & 0.062 & 0,05 & Normal \\
\hline
\end{tabular}

Source: Author' elaboration.

Based on Table 5, it can be seen that the results of the normality variable test of accountability, transparency, supervision, and budget performance are normally distributed because the sign value is greater than $5 \%$. Thus, hypothesis testing can be done using parametric statistics.

\subsection{Linearity Test}

The results of processing linearity test data with the SPSS version 20.0 program are as follows:

Table 6. Linearity Test

\begin{tabular}{|c|c|c|c|c|}
\hline Model & $\mathbf{R}$ & R Square & Adjusted R Square & $\begin{array}{c}\text { Std. Error of the } \\
\text { Estimate }\end{array}$ \\
\hline 1 & $0.880^{\mathrm{a}}$ & 0.775 & 0.762 & 0.2729 \\
\hline
\end{tabular}

Source: Author' elaboration. 
Based on the results of SPSS output shows that the value of R Square of 0.775 with the number of research $n 58$, then the value of $c 2$ count $=58 \times 0.775=44.95$. This value is compared with c2 table with $\mathrm{df}=58$ significance level of 0.05 , obtained c2 table value of 76,778 . Because the value of $c 2$ count is smaller than $c 2$ table, it can be concluded that the regression model in this study is linear.

\subsection{Simple Linear Regression Analysis}

Based on Table 7, it can be seen that the $t$ value of the accountability variable is 2.734. When compared with the value of $t$ table at a significance level of $5 \%$ that is equal to 2.004, then the value of $t$ count is greater than $t$ table (2.734> 2.004), indicating that the effect of the variable accountability on budget performance with the concept of value for money is significant. This is supported by the value of sig / $\mathrm{p}$ value 0.000 smaller than the value of $\alpha=5 \%$. Based on the hypothesis test, it can be concluded that the accountability variable has a positive and significant effect on budget performance with the concept of value for money.

Table 7. Regression Test Output

\begin{tabular}{|c|c|c|c|c|c|c|}
\hline No & Variable & t Count & $\mathbf{t}$ Table & Sig (p) & Value & Information \\
\hline 1 & Accountability (X1) & 2.734 & 2.004 & 0.00 & 0.05 & Ho Refused \\
\hline 2 & Transparency (X2) & 4.490 & 2.004 & 0.00 & 0.05 & Ho Refused \\
\hline 3 & Supervision (X3) & 2.999 & 2.004 & 0.00 & 0.05 & Ho Refused \\
\hline
\end{tabular}

Source: Author' elaboration.

For the transparency variable, the calculated $t$ value is greater than $t$ table $(4.490>2.004)$, indicating that the effect of the variable transparency on budget performance with the concept of value for money also has a significant effect. This is supported by the value of sig / $p$-value 0.000 smaller than the value of $\alpha=5 \%$. Based on the hypothesis test, it can be concluded that the transparency variable has a positive and significant effect on budget performance with the concept of value for money.

For supervision variables, the value of $t$ count is greater than t table (1999> 2.004), indicating that the effect of the supervision variable on budget performance with the concept of value for money also has a significant effect. This is supported by the value of sig / $p$-value 0.000 smaller than the value of $\alpha=5 \%$. Based on the hypothesis test, it can be concluded that the supervision variable has a positive and significant effect on budget performance with the concept of value for money. 


\subsection{Effect of Simultaneous Accountability, Transparency and Supervision on Budget Performance}

To test Accountability, Transparency and Simultaneous Supervision of Budget Performance, the $\mathrm{F}$ test was used. The $\mathrm{F}$ test results can be seen in Table 8 .

Table 8. Result of F Test

\begin{tabular}{|c|c|c|c|c|c|c|c|}
\hline No & Variable & F Count & F Table & Sign & Constant & Coefficient & Information \\
\hline 1 & Accountability & 20.571 & 3.16 & 0.00 & 0.462 & 0.544 & Ho Refused \\
2 & Transparency & & & & & 0.102 & \\
3 & Supervision & & & & & 0.214 & \\
\hline
\end{tabular}

Source: Author' elaboration.

Based on these results, the regression equation can be made as follows:

Budget Performance with the Value for Money Concept $(\mathrm{Y})=0.462+0.544$ (X1 Accountability) +0.102 (X2 Transparency) +0.214 (X3 Supervision)

It means that if all the independent variables, namely accountability, transparency, and supervision are considered constant, then the value of the dependent variable, namely budget performance with the concept of value for money will be obtained at 0.462 .

Based on Table 8, it can be seen that F count is 20.571 . When compared with the value of $F$ table at a significance level of $5 \%$ that is equal to 3.16 , then the calculated $F$ value is greater than $F$ table $(20.571>3.16)$, in line with the significant value (sig) of $0.00<0.05$ which indicates an alternative hypothesis is accepted. This means that accountability (X1), transparency (X2) and supervision (X3) simultaneously influence the budget performance of the Regional Government Owned Enterprises of Riau Province.

Based on the hypothesis test, it can be concluded that the variables of accountability, transparency, and supervision have a positive and significant effect on budget performance with the concept of value for money. Thus, the hypothesis which states that accountability, transparency, and supervision has a positive effect together on budget performance with the concept of value for money on BUMD, is accepted.

This research is in line with the research conducted by Anugriani (2014) which shows that accountability has a positive and significant effect on budget performance with the concept of value for money. This study also supports Wandari's (2015) research which shows that accountability has a significant positive effect on the performance of the budget concept of value for money in government agencies in Buleleng Regency. 


\section{Conclusions and Suggestions}

\subsection{Conclusion}

Accountability has a positive and significant effect on Budget Performance in Regional-Owned Enterprises (BUMD). This is indicated by the regression coefficient value which is positive and the value of $t$ count is greater than the value of $t$ table and the significance value is smaller than the significance value of $5 \%$. But there are still answers from respondents who strongly disagree and disagree that is equal to $8.81 \%$ of budget making involving stakeholders such as investors and government, budget evaluation is done by comparing targets with realization, and the budget that is accountable to more authorities high.

Transparency has a positive and significant effect on Budget Performance in Regional-Owned Enterprises (BUMD). This is indicated by the regression coefficient value which is positive and the value of $t$ count is greater than the value of $t$ table and the significance value is smaller than the significance value of $5 \%$. However, there are still respondents who strongly disagree and disagree that is equal to $6.33 \%$ of the convenience of stakeholders (investors and the government) to access company documents regarding the Corporate Work Plan and Budget (RKAP).

Supervision has a positive and significant effect on Budget Performance with Regional-Owned Enterprises (BUMD). This is indicated by the regression coefficient value which is positive and the value of $t$ count is greater than the value of $t$ table and the significance value is smaller than the significance value of $5 \%$. But there were still answers from respondents, which amounted to $4.22 \%$, which strongly disagreed and disagreed with the roles of accountants and SPI employees in providing input when preparing budget policies, stakeholder aspirations (investors and government) became the basis for budgeting, and committees audit that helps the supervisory board oversee the management of the Company's Work Plan and Budget (RKAP).

Accountability, Transparency and Supervision simultaneously have a positive and significant effect on Budget Performance in Regional-Owned Enterprises (BUMD). This is indicated by the regression coefficient value which is positive and the calculated $F$ value is greater than the $F$ table value and the significance value is smaller than the $5 \%$ alpha value.

\section{References}

Abdul H., \& Abdullah, S. (2006). "Hubungan dan Masalah Keagenan di Pemerintah Daerah: Sebuah Peluang Penelitian Anggaran dan Akuntansi", Jurnal Akuntansi Pemerintah, 2, 53-64.

Anugriani, R. M. (2014). “Pengaruh Akuntabilitas, Transparansi, dan Pengawasan Terhadap Kinerja Anggaran Berkonsep Value for Money Pada Instansi Pemerintah di Kabupaten Bone", Skripsi, Universitas Hasanudin, Makasar. 
Bachtiar A. (2002). Akuntansi Pemerintahan, Salemba Empat, Jakarta.

Hladchenko, Li. (2016). "Government Financial Accountability and Transparency in the Digital World", ICTERI 2016, Kyiv, Ukraine, June 21-24, 2016, 477-483

Imam G. (2011). Aplikasi Analisis Multivariate dengan Program SPSS, Universitas Diponegoro, Semarang.

Indra B. (2001). Akuntansi Sektor Publik di Indonesia, BPFE, Yogyakarta.

Keputusan Presiden Nomor 74 Tahun 2001 Tentang Tata Cara Pengawasan Penyelenggaraan Pemerintah Daerah (2001). Republik Indonesia, Jakarta.

Loina Lalolo Krina P. (2003). Indikator \& Alat Ukur Prinsip Akuntabilitas, Transparansi \& Partisipasi. Sekertariat Good Public Governance Badan Perencanaan Pembangunan Nasional, Jakarta.

Mahmudi. (2005). Manajemen Kinerja Sektor Publik, UPP AMP YKPN, Yogyakarta.

Mardiasmo. (2002). Akuntansi Sektor Publik, CV Andi Offset, Yogyakarta.

Mardiasmo. (2002). “Controlling, Monitoring, and Auditing of Provincial Govermental Performance in Regional Autonomy Implementation", Journal Business and Accounting, 3(2), 441-456

Muhammad F. A. (2015). "Akuntabilitas, Transparansi, dan Anggaran Berbasis Kinerja Pada Satuan Kerja Perangkat Daerah Kota Denpasar", Jurnal Akuntansi Universitas Udayana. 11(2), 611-628.

Nico A. (2007). Good e-Government: Transparansi dan Akuntabilitas Publik Melalui eGovernment, Bayumedia Publishing, Malang.

Osho, Augustine E., \& Afolabi, Matthew B. (2014). "The effects and effectiveness of Accountability and Transparency in Government Sectors", IOSR Journal of Business and Management (IOSR-JBM), 16(4), Ver. V, 46-54.

Rezky Mulya A. (2014). Pengaruh Akuntabilitas, Transparansi, dan Pengawasan Terhadap Kinerja Anggaran Berkonsep Value for Money Pada Instansi Pemerintah di Kabupaten Bone. Skripsi, Universitas Hasanudin Makasar, Makasar.

Sugiyono. (2011). Metode Penelitian Kuantitatif, Kualitatif, dan R\&D, Alfabeta, Bandung.

Surianti, M. \& Dalimunthe, Abdul R. (2017). "The Implementation of Performance Based Budgeting in Public Sector (Indonesia Case: a Literature Review)", International Journal of Developing and Emerging Economies, 5(2), 52-67

Taufiqurrahman. 2014. "The Implementation of Performance Based Budgetting: Challenges and Barriers in the Provincial Level", Public Administration Network, 6(2), 511-519.

Wandiri, I. D. N. Tri, dkk. (2015). "Pengaruh Akuntabilitas, Transparansi, Ketepatan Waktu dan Pengawasan Internal Terhadap Kinerja Berkonsep Value for 
Money Pada Instansi Pemerintah di Kabupaten Buleleng", Jurnal Akuntansi. 3(1), 1-12.

Osho, Augustine E. \& Afolabi, Matthew B. "The effects and effectiveness of Accountability and Transparency in Government Sectors", IOSR Journal of Business and Management, (IOSR-JBM), 16(4), Ver. V (Apr. 2014), 46-54

Purwono, Herry. (2010). Dasar-Dasar Perpajakan dan Akuntansi Pajak, Erlangga, Yogyakarta.

Rahman, A. (2010). Panduan Pelaksanaa Administrasi Perpajakan, Penerbit Nuansa, Bandung.

Republik Indonesia, Undang-Undang Nomor 28 Tahun 2007 tentang Perubahan Ketiga atas UndangUndang Nomor 6 Tahun 1983 tentang Ketentuan Umum dan Tata CaraPerpajakkan.

Resmi, S. (2014). Perpajakan Teori dan Kasus, Salemba Empat, Jakarta.

Risky, D. (2015), “Analisis FaktorFaktor Yang Mempengaruhi Intensitas Perilaku Dalam Penggunaan Sistem E-Filling", Jurnal Administrasi Bisnis-Perpajakan $(J A B), 6(1)$.

Setiawan. H., \& Safri, M. (2016). "Analisis Pengaruh Akuntabilitas Publik, Transparansi Publik dan Pengawasan Terhadap Kinerja Satuan Kerja Perangkat Daerah di Kabupaten Bungo", Jurnal Perspektif Pembiayaan dan Pembangunan Daerah, $4(1), 51-72$.

Suandy, E. (2011). Perencanaan Pajak, Edisi Keempat, Jakarta: Salemba Empat. Supramono dan Theresia Woro Damayanti. (2010), Perpajakan Indonesia Mekanismedan Perhitungan, Andi Offset, Yogyakarta.

Tambun, S. (2016). "Pengaruh Kesadaran Wajib Pajak Dan Penerapan E-System Terhadap Tingkat Kepatuhan Wajib Pajak Dengan Preferensi Resiko Sebagai Variabel Moderating", Media Akuntansi Perpajakan, 1(2), 86-94.

Tuasikal, A. (2008). "Pengaruh Pengawasan, Pemahaman Sistem Akuntansi Keuangan dan Pengelolaan Keuangan Terhadap Kinerja Unit Satuan Kerja Pemerintah Daerah. (Studi pada Kabupaten dan Kota di Provinsi Maluku)", Jurnal Keuangan dan Perbankan, 10(1).

Waluyo. (2013). Perpajakan Indonesia, Edisi Kesebelas, Salemba Empat, Jakarta.

Zuhdi, Firdaus A. (2015). "Pengaruh Penerapan E-Spt Dan Pengetahuan Perpajakan Terhadap Kepatuhan Wajib Pajak (Studi Pada Pengusaha Kena Pajak yang terdaftar di KPP Pratama Singosari)", Jurnal Perpajakan (JEJAK), 7(1), 1-7. 